PUBLIK: Jurnal Manajemen Sumber Daya Manusia, Administrasi dan Pelayanan Publik Sekolah Tinggi Ilmu Administrasi Bina Taruna Gorontalo Volume V Nomor 2 Desember 2018

\title{
FAKTOR-FAKTOR PENGHAMBAT PEMELIHARAAN SARANA AIR BERSIH DI DESA INOSOTA KECAMATAN POSIGADAN KABUPATEN BOLAANG MONGONDOW SELATAN
}

\author{
Isran Pakaya \& Andi Yusuf Katili \\ STIA Bina Taruna Gorontalo \\ bukujurnalstia@binataruna.ac.id ${ }^{1} \&$ yusuf2801@gmail.com2
}

\begin{abstract}
ABSTRAK
Penelitian ini bertujuan untuk mengetahui faktor-faktor penghambat pemeliharaan sarana air bersih di Desa Inosota Kecamatan Posigadan Kabupaten Bolaang Mongondow Selatan. Metode penelitian menggunakan jenis deskriptif pendekatan kualitatif. Teknik pengumpulan data dilakukan melalui wawancara mendalam kepada sejumlah informan, observasi dan pencatatan data sekunder yang berkaitan dengan permasalahan penelitian.

Hasil penelitian menyimpulkan bahwa, Keberadaan petugas kurang optimal dalam melakukan pemeliharaan sarana air bersih. Hal ini tampak dari sarana air bersih atau bak air yang tidak lagi berfungsi dalam mengaliri air bersih kerumah-rumah warga karena kondisinya yang telah rusak. Pengawasan pemeliharaan sarana air bersih belum optimal. Hal ini tampak dari tidak adanya pihak dari instansi terkait yang datang untuk melihat kondisi sarana air bersih yang tidak lagi berfungsi dan kondisi masyarakat desa inosota yang sangat kesusahan air bersih. Koordinasi pemeliharaan sarana air bersih belum optimal. Hal ini tampak dari tidak adanya struktur pengelolaan air bersih hingga ke tingkat desa dan tidak optimalnya komunikasi antara pihak ang satu dengan pihak lainya dan saling lempar tanggungjawab.

Disarankan, perlunya petugas yang dapat melakukan pemeliharaan dan perawatan sarana air bsersih, serta perlunya pembekalan melalui bimbingan teknis yang paripurna. Diperlukan adanya pengawasan langsung oleh pemerintah dalam rangka memantau pelaksanaan penyaluran air bersih yang disertai dengan pendanaan bagi petugas pelaksana. Diperlukan adanya koordinasi diantara semua pihak terkait sehingga pelaksanaan pemeliharaan sarana air bersih bisa dilakukan secara maksimal.
\end{abstract}

Kata Kunci: Pemeliharaan; Sarana; Air Bersih

\section{PENDAHULUAN}

Air bersih adalah air yang digunakan untuk keperluan sehari-hari dan akan menjadi air minum setelah dimasak terlebih dahulu. Sebagai batasannya, air bersih adalah air yang memenuhi persyaratan bagi sistem penyediaan air minum. Adapun persyaratan yang dimaksud adalah persyaratan dari segi kualitas air yang 
PUBLIK: Jurnal Manajemen Sumber Daya Manusia, Administrasi dan Pelayanan Publik Sekolah Tinggi Ilmu Administrasi Bina Taruna Gorontalo

Volume V Nomor 2 Desember 2018

meliputi kualitas fisik, kimia, biologi, dan radiologis, sehingga apabila dikonsumsi tidak menimbulkan efek samping.

Penyediaan air bersih untuk masyarakat mempunyai peranan yang sangat penting dalam meningkatkan kesehatan lingkungan atau masyarakat, yakni mempunyai peranan dalam menurunkan angka penderita penyakit, khususnya yang berhubungan dengan air, dan berperan dalam meningkatkan standar atau taraf/kualitas hidup masyarakat.

Sampai saat ini, penyediaan air bersih untuk masyarakat di Indonesia masih dihadapkan pada beberapa permasalahan yang cukup kompleks dan sampai saat ini belum dapat diatasi sepenuhnya. Salah satu masalah yang masih dihadapi sampai saat ini yakni pelayanan air bersih untuk masyarakat. Di Negara kita ini masalah lainnya yang perlu dipikirkan adalah tentang bagaimana menjaga dan mengelola air hingga tetap dapat dinikmati sepanjang waktu oleh seluruh lapisan masyarakat yang ada di Indonesia. Pada kenyataannya bahwa sumber daya air khususnya air bersih sudah mulai terbatas dan sangat sulit untuk bisa dinikmati oleh sebagian masyarakat khususnya masyarakat yang ada di perdesaan dan sangat jauh dari sumber air bersih.

Dengan keterbatasan ini, sungguh keliru jika orang mengeksploitasi air secara berlebih. Mereka memanfaatkan air seolah-olah air berlimpah dan merupakan barang bebas. Padahal semakin terbatas jumlahnya, berlakulah hukum ekonomi, bahwa air merupakan benda ekonomis. Buktinya, kini orang rela bersusah-susah dan berani membayar mahal untuk membeli air ketika terjadi krisis air. Masyarakat desa di negara tropis seperti Indonesia, harus berjalan puluhan kilometer untuk mencari sumber air di musim kemarau. Sementara masyarakat perkotaan belum semuanya mendapatkan pelayanan air bersih, baik kuantitas maupun kualitas.

Penyediaan air bersih di Indonesia terutama di perdesaan masih menghadapi berbagai kendala yang kompleks, mulai dari kelembagaan, teknologi, anggaran, pencemaran, maupun sikap dari masyarakat. Tidak jauh berbeda dengan permasalahan yang terjadi di Desa Inosota Kecamatan Posigadan Kabupaten Bolaang Mongondow Selatan. Ketersediaan air bersih cukup memprihatikan khususnya keberadaan sarana air bersih yang tidak lagi terawat dengan baik oleh pemerintah setempat dan masyarakat itu sendiri. Jumlah sarana air bersih yang ada di Desa Inosota adalah dua (2) buah dan dimanfaatkan oleh sekitar 643 penduduk. Sarana air bersih di bangun dalam bentuk penampungan (bak air) yang terdiri dari 8 bak yang ada di hulu sungai desa yang kemudian disalurkan ke rumah-rumah penduduk dengan biaya perbulan per tiap rumah tangga sebesar Rp.15.000. Pembangunan sarana air di Desa Inosota sangat membantu masyarakat setempat dalam memenuhi kebutuhan air bersih, hanya saja pembangunan sarana air bersih tidak lagi seperti di awal pembangunannya.

Beberapa faktor yang menjadikan pemeliharaan sarana air di Desa Inosota 
tidak lagi efektif, di antaranya; Pertama, kurangya kinerja petugas yang melakukan pemeliharaan terhadap keberadaan sarana air bersih dan bahkan dalam kurun waktu 2 (dua) tahun terakhir tidak tampak lagi adanya petugas yang datang melakukan pemeliharaan dan hal ini diperparah dengan perilaku masyarakat Inosota itu sendiri yang tidak menjaga sarana air bersih sehingga sarana air yang ada sering tercemar limbah masyarakat sehingga menjadikan air bersih tidak layak untuk digunakan baik untuk kebutuhan mandi, mencuci, ataupun dikonsumsi. Kedua, lemahnya pengawasan yang dilakukan oleh pemerintah akan keberadaan sarana air di Desa Inosota. Pembangunan sarana air di Desa Inosota tidak terencana dengan baik, hal ini terlihat dari tidak adanya badan/kelembagaan atau orang yang ditugaskan atau bertanggungjawab untuk menjaga dan merawat sarana air yang ada. Ketiga, pembangunaan sarana air di Desa Inosota tidak lagi efektif untuk bisa digunakan dan dinikmati masyarakat dikarenakan tidak adanya koordinasi dan komunikasi antara pihak-pihak terkait baik dari masyarakat maupun dari pemerintah untuk menjaga dan mengelola sarana air yang ada.

\section{PERMASALAHAN}

Berdasarkan uraian latar belakang tersebut, maka rumusan masalah dalam penelitian ini adalah; Faktor-faktor apa saja yang menghambat pemeliharaan sarana air bersih di Desa Inosota Kecamatan Posigadan Kabupaten Bolaang Mongondow Selatan?

\section{Tujuan Penelitian}

Adapun tujuan penelitian yang ingin dicapai dalam penelitian ini dengan melihat rumusan masalah di atas adalah; untuk mengetahui faktor-faktor penghambat pemeliharaan sarana air bersih di Desa Inosota Kecamatan Posigadan Kabupaten Bolaang Mongondow Selatan.

\section{METODE PENELITIAN}

Jenis penelitian ini adalah penelitian deskriptif metode kualitatif. Penelitian deskriptif kualitatif yaitu jenis penelitian berdasarkan pendekatan yang digunakan yakni penelitian yang dilakukan pada kondisi obyek yang alami, dimana peneliti sebagai instrumen utamanya/instrumen kunci, teknik pengumpulan data dilakukan secara gabungan hingga datanya jenuh dan menghasilkan data bersifat deskriptif (Wirartha, 2006: 134).

\section{Fokus Penelitian}

Adapun penelitian mengenai Faktor-Faktor Penghambat Pemeliharaan Sarana Air Bersih di Desa Inosota Kecamatan Posigadan Kabupaten Bolaang Mongondow Selatan.

\section{Petugas}

Petugas yang dimaksudkan dalam penelitian ini adalah petugas yang melakukan pemeliharaan terhadap sarana air bersih yang ada di Desa Inosota Kecamatan Posigadan.

\section{Pengawasan}

Pengawasan Pemerintah yang dimaksud dalam penelitian ini adalah pemantauan 
PUBLIK: Jurnal Manajemen Sumber Daya Manusia, Administrasi dan Pelayanan Publik Sekolah Tinggi Ilmu Administrasi Bina Taruna Gorontalo

Volume V Nomor 2 Desember 2018

dari pihak pemerintah agar sarana air yang ada di Desa Inosota bisa terawat dengan baik.

\section{Koordinasi}

Koordinasi yang dimaksud dalam penelitian ini adalah bentuk komunikasi yang dilakukan oleh pemerintah dengan pihak lainnya dalam menjaga keberadaan sarana air di Desa Inosota.

\section{HASIL PENELITIAN DAN PEMBAHASAN}

Sarana air bersih merupakan salah satu kebutuhan pokok manusia yang diperoleh dari berbagai sumber, tergantung pada kondisi daerah setempat. Kondisi sumber air pada setiap daerah berbeda-beda, tergantung pada keadaan alam dan kegiatan manusia yang terdapat di daerah tersebut. Penduduk yang tinggal di daerah kesulitan memperoleh air bersih untuk keperluan rumah tangga, terutama air minum. Terdapat beberapa kendala yang menyebabkan masih tingginya jumlah orang yang belum terlayani fasilitas air bersih dan sanitasi dasar. Di antaranya adalah cakupan pembangunan yang sangat besar, sebaran penduduk yang tidak merata dan beragamnya wilayah Indonesia, keterbatasan sumber pendanaan. Pemerintah selama ini belum menempatkan perbaikan fasilitas sanitasi sebagai prioritas dalam pembangunan. Faktor lain yang juga menjadi kendala adalah kualitas dan kuantitas sumber air baku sendiri terus menurun akibat perubahan tata guna lahan (termasuk hutan) yang mengganggu sistem siklus air. Selain itu, meningkatnya kepadatan dan jumlah penduduk di perkotaan akibat urbanisasi.

Kaitannya dalam penelitian ini bahwa pemeliharaan sarana air bersih di Desa Inosota Kecamatan Posigadan Kabupaten Bolaang Mongondow Selatan juga mengalami hal yang sama, dimana sarana air bersih yang sudah dibangun tidak lagi berfungsi dalam mengaliri air bersih kerumah-rumah warga. Akibatnya, saat ini masyarakat desa Inosota sangat kesulitan untut mendapatkan air bersih dan tak jarang warga harus pergi ke desa tetangga untuk mendapatkan air bersih.

Beberapa

faktor-faktor penghambat dalam pemeliharaan sarana air bersih di Desa Inosota Kecamatan Posigadan Kabupaten Bolaang Mongondow Selatan, diantaranya jumlah petugas, pengawasan pemerintah dan koordinasi. Berikut akan dilakukan uraian pembahasan dengan fokus penelitian tersebut.

Pertama, petugas. Kegiatan operasional dan pemeliharaan diperlukan pada setiap bangunan penyediaan air bersih, hal ini diperlukan untuk menjaga kelestarian fungsi dari bangunan-bangunan tersebut. Oleh karena itu, peran petugas sangat penting di dalam menjaga dan memelihara sarana air bersih. Agar supaya prasarana tetap dapat beroperasi optimal, maka petugas perlu mengambil langkah pencegahan yaitu: Pengurus aktif menagih iuran anggotanya, pengurus akomodatif menjelaskan tugas pembersihan, dan pengurus mampu menyusun rencana pemeliharaan. Adapun Langkah-langkah dalam pemeliharaan kesinambungan: survei 
PUBLIK: Jurnal Manajemen Sumber Daya Manusia, Administrasi dan Pelayanan Publik Sekolah Tinggi Ilmu Administrasi Bina Taruna Gorontalo

Volume V Nomor 2 Desember 2018

kebutuhan pemeliharaan, analisis masalah pemeliharaan dan tindakan pemeliharaan. Namun demikian, dibutuhkan kualitas dan kuantitas petugas di dalam menjaga sarana air bersih sehingga kemanfaatannya bisa dinikmati secara berkelanjuta.

Demikian halnya dalam penelitian ini, bahwa yang dimaksud dalam penelitian ini adalah jumlah petugas yang melakukan pemeliharaan terhadap sarana air bersih yang ada di Desa Inosota Kecamatan Posigadan. Berdasarkan hasil penelitian dan analisis penulis dapat diketahui bahwa tidak ada petugas yang melakukan pemeliharaan sarana air bersih. Hal ini tampak dari sarana air bersih atau bak air yang tidak lagi berfungsi dalam mengaliri air bersih kerumah-rumah warga karena kondisinya yang telah rusak.

Kedua, pengawasan pemerintah. Suatu organisasi akan berjalan terus dan semakin komplek dari waktu ke waktu, banyaknya orang yang berbuat kesalahan dan guna mengevaluasi atas hasil kegiatan yang telah dilakukan, inilah yang membuat fungsi pengawasan semakin penting dalam setiap organisasi. Tanpa adanya pengawasan yang baik tentunya akan menghasilkan tujuan yang kurang memuaskan, baik bagi organisasinya itu sendiri maupun bagi para pekerjanya. Fungsi pengawasan ialah untuk memberikan nilai, analisis, merekomendasikan dan menyampaikan hasil laporan atau surat yang berhubungan dengan bidan pekerjaan sebuah lembaga atau organisasi yang telah diteliti.
Dalam penelitian ini kemudian ditafsirkan bahwa, pengawasan pemerintah yang dimaksud dalam penelitian ini adalah pemantauan dari pihak pemerintah agar sarana air yang ada di Desa Inosota bisa terawat dengan baik. Berdasarkan hasil penelitian dan analisis penulis dapat diketahui bahwa pengawasan pemeliharaan sarana air bersih belum optimal. Hal ini tampak dari tidak adanya pihak dari instansi terkait yang datang untuk melihat kondisi sarana air bersih yang tidak lagi berfungsi dan kondisi masyarakat desa inosota yang sangat kesusahan air bersih.

Ketiga,

koordinasi. Koordinasi adalah suatu sinkronisasi yang tertib dalam upaya untuk memberikan jumlah yang tepat, waktu dan mengarahkan pelaksanaan yang mengakibatkan harmonis dan tindakan terpadu untuk tujuan lain. Pandangan mengenai koordinasi ini menarik perbedaan antara koordinasi dengan kerja sama. Kerja sama diartikan sebagai aksi kolektif satu orang dengan yang lain atau orang lain menuju tujuan bersama.

Jika dilihat dari sudut normatifnya, maka koordianasi diartikan sebagai kewenangan untuk menggerakkan, menyelaraskan, menyerasikan dan menyeimbangkan kegiatan-kegiatan yang spesifik atau berbeda, agar nantinya semua terarah pada pencapaian tujuan tertentu pada waktu yang telah ditetapkan. Dari sudut fungsionalnya, koordinasi dilakukan guna mengurangi dampak negatif spesialisasi dan mengefektifkan pembagian kerja. 
PUBLIK: Jurnal Manajemen Sumber Daya Manusia, Administrasi dan Pelayanan Publik Sekolah Tinggi Ilmu Administrasi Bina Taruna Gorontalo

Volume V Nomor 2 Desember 2018

Dalam penelitian ini, yang dimaksudkan dengan koordinasi adalah bentuk komunikasi yang dilakukan oleh pemerintah dengan pihak lainnya dalam menjaga keberadaan sarana air di Desa Inosota. Berdasarkan hasil penelitian dan analisis penulis dapat diketahui bahwa koordinasi pemeliharaan sarana air bersih belum optimal. Hal ini tampak dari tidak adanya struktur pengelolaan air bersih hingga ke tingkat desa dan tidak optimalnya komunikasi antara pihak ang satu dengan pihak lainya dan saling lempar tanggungjawab.

Secara keseluruhan dapat disimpulkan bahwa pemeliharaan sarana air bersih di Desa Inosota Kecamatan Posigadan Kabupaten Bolaang Mongondow Selatan belum optimal. Hal tersebut dikarenakan tidak adanya petugas yang melakukan pemeliharaan, lemahnya pengawasan yang dilakukan oleh pemerintah, dan tidak maksimalnya koordinas yang dilakukan oleh pihakpihak terkait.

\section{SIMPULAN}

Berdasarkan hasil penelitian dan pembahasan, maka dapat disimpulkan sebagai berikut:

1. Keberadaan petugas kurang optimal dalam melakukan pemeliharaan sarana air bersih. Hal ini tampak dari sarana air bersih atau bak air yang tidak lagi berfungsi dalam mengaliri air bersih kerumah-rumah warga karena kondisinya yang telah rusak.

2. Pengawasan pemeliharaan sarana air bersih belum optimal. Hal ini tampak dari tidak adanya pihak dari instansi terkait yang datang untuk melihat kondisi sarana air bersih yang tidak lagi berfungsi dan kondisi masyarakat desa inosota yang sangat kesusahan air bersih.

3. Koordinasi pemeliharaan sarana air bersih belum optimal. Hal ini tampak dari tidak adanya struktur pengelolaan air bersih hingga ke tingkat desa dan tidak optimalnya komunikasi antara pihak ang satu dengan pihak lainya dan saling lempar tanggungjawab.

4. Secara keseluruhan dapat disimpulkan bahwa pemeliharaan sarana air bersih di Desa Inosota Kecamatan Posigadan Kabupaten Bolaang Mongondow Selatan belum optimal. Hal tersebut dikarenakan tidak adanya petugas yang melakukan pemeliharaan, lemahnya pengawasan yang dilakukan oleh pemerintah, dan tidak maksimalnya koordinas yang dilakukan oleh pihakpihak terkait.

\section{SARAN}

Berdasarkan dengan hasil penelitian dan kesimpulan di atas, maka adapun beberapa saran yang dapat dikemukakan adalah:

1. Diperlukan petugas yang dapat melakukan pemeliharaan dan perawatan sarana air bsersih, serta perlunya pembekalan melalui bimbingan teknis yang paripurna, agar kemampuan petugas pelaksana dilapangan dalam memahami pekerjaannya dapat secara maksimal.

2. Diperlukan adanya pengawasan langsung oleh pemerintah dalam rangka memantau pelaksanaan penyaluran air bersih yang disertai 
PUBLIK: Jurnal Manajemen Sumber Daya Manusia, Administrasi dan Pelayanan Publik Sekolah Tinggi Ilmu Administrasi Bina Taruna Gorontalo Volume V Nomor 2 Desember 2018

dengan pendanaan bagi petugas pelaksana, agar pelaksanaannya dilapangan tidak menemui hambatan dan kendala.

3. Diperlukan adanya koordinasi diantara semua pihak terkait sehingga pelaksanaan pemeliharaan sarana air bersih bisa dilakukan secara maksimal.

4. Perlunya dilakukan upaya pemeliharaan sarana air bersih dengan merekrut petugas yang berkualitas, meningkatkan dan memaksimalkan pengawasan, serta membangun koordinasi yang baik diantara semua pihak terkait.

\section{DAFTAR PUSTAKA}

Alex, Sobur. 2010. Psikologi Umum dalam Lintasan Sejarah. Jakarta: Pustaka Setia.

A.M. Sardiman. 2007. Interaksi dan Motivasi Belajar Mengajar: Bandung: Rajawali Pers.

Abdul, Aziz Thohir 2009. Etika Bekerja Dalam Islam. Jakarta: Gema Insani Press.

Andi, 2009. Membangun Aplikasi Bisnis Dengan Netbeans 7. Yogyakarta: Wahana Komputer.

Arikunto, Suharsimi. 2009. Prosedur Penelitian: Suatu Pendekatan Praktek. Jakarta: Rinka Cipta.

Arikunto, Suharsimi, 2009. Manajemen Perbankan. Gunung Agung. Jakarta

Atmodowirdjo. 2006. Peran Disiplin Pada Perilaku dan Prestasi Siswa. Jakarta: Grasindo.
Azwar, Saifuddin. 2010. Penyusunan Skala Psikologi. Yogyakarta: Pustaka Pelajar.

Fathoni, Abdurrahmat DV. 2006. Organisasi dan Manajemen Sumber Daya Manusia. Bandung: PT. Rineka Cipta.

Hasibuan, Malayu. 2008. Manajemen Sumber Daya Manusia. Edisi Revisi. Jakarta: PT. Bumi Aksara.

Hasibuan, Malayu. 2005. Manajemen Sumber Daya Manusia. Edisi Revisi. Jakarta: Bumi Aksara.

Mardiyanto, 2008. Kewirausahaan. Surakarta: Yudhistira

Masong. 2011. Etos Kerja Islam. Jakarta: Pedoman Ilmu Jaya.

Musanef. 2004. Manajemen Kepegawaian di Indonesia. Cetakan ke- 2. Jakarta: PT. Gunung Agung.

Notoatmodjo, S. 2007. Promosi Kesehatan dan Ilmu Perilaku. Jakarta: Rineka Cipta.

Sinamo, Jansen. 2007. Etos Kerja Profesional di Era Digital Global, Ed 1. Jakarta: Institut Darma Mahardika.

Siswanto, Bedjo. 2001. Manajemen Tenaga Kerja, Rancangan Dalam Pendayagunaan dan Pengembangan Unsur Tenaga Kerja. Bandung: Sinar Baru

Sugiyono. 2010. Metode Penelitian Kuantitatif Kualitatif dan $R \& D$, Ed. Revisi Cet. Ke -10, Bandung: CV. Alfabeta.

Suryana. 2006. Kewirausahaan: Pedoman Praktis, Kiat dan Proses Menuju Sukses. Jakarta: Salemba Empat. 
Toto, Tasmara. 2010. Etos Kerja Pribadi Muslim. Yogyakarta: PT. Dana Bhakti Wakaf.

Wahid, Iqbal., dkk. 2006. Ilmu Keperawatan Komunitas. Jakarta: CV Sagung Seto.

Widjaja. 2010. Otonomi Desa. Jakarta: Raja Grafindo Persada.

Wirartha, I Made. 2006. Metode Penelitian Sosial ekonomi, Yogyakarta: PT. Andi Offset.

\section{Dokumen Lain;}

Undang-Undang Dasar 1945 alinea IV.

Undang-Undang Nomor 32 Tahun 2004 tentang Pemerintahan Daerah.

Undang-Undang Nomor 12 Tahun 2008 tentang Pemerintahan Daerah.

Undang-Undang Nomor 23 Tahun 2014 tentang Pemerintahan Daerah.

Peraturan Pemerintah Nomor 41 Tahun 2007 tentang Organisasi

Perangkat Daerah. 